\title{
ReVIEWS
}

\author{
Julia Kołodziejska * \\ Svetlozar Dimitrov **
}

\section{PAWEŁ PIENIĄŻEK „POZDROWIENIA Z NOWOROSJI”, WARSAW 2015, PUBLISHED BY KRYTYKA POLITYCZNA, ss. 235. (REV.)}

The subject of this analysis is the publication of "Pozdrowienia z Noworosji" by Pawel Pieniążek. After the bloody events on the Maidan and the Russian annexation of the Crimea Ukrainian society was once again forced to redefine their own vision of development of the state. Pro-Russian separatists targeted the Donetsk coal-mining area, the area covering the circumference of Donetsk and Luhansk were to become part of Russia called Novorossiya. Initially, the desire to create a new region was visible only through demonstrations, but the situation quickly exacerbated into a developing open armed conflict supported by the Russian authorities. The reviewed book is an interesting form of a presentation and an attempt to analyze the events that resulted from the above state of affairs, and took place from March to December 2014. It can be argued that they were the tragic effects arising as a result of actions taken by the Ukrainian society to implement the European values such as the right to self-determination or the broad civil liberties such as the freedom of speech or the right to protest. The author of the analyzed publication specializes in matters concerning the Eastern Europe. He graduated from the Chair Department of Ukrainian Studies at the University of Warsaw. Since 2012 he has worked as editor-in-chief of the magazine "New Eastern Europe", and since 2013 he regularly reports on events taking place in Ukraine. He was on the side of separatists in Donbas many times and on the front-line of Ukrainian troops. The discussed item is largely composed of materials collected for the author's articles published in "Tygodnik Powszechny".

* Faculty of Political Sciences and International Studies, Nicolaus Copernicus University in Toruń, Poland

** University of Veliko Turnovo St Cyril and St. Methodius, Bulgaria 
The reviewed book, due to its immediate release, is an up-to-date message. Its appearance is correlated with the moment of conducting subsequent peace talks on resolving the crisis in eastern Ukraine. The study can be regarded as an extension of recently available information on areas of the conflict. The research problem and the purpose of the publication is to present the birth of the conflict, its course and consequences of the many different points of view covered by an eyewitness. This study is a persuasive look at the situation taking place in Ukraine. Although the book was written in the form of reportage, it contains the values of scientific research. But it is possible to distinguish, except for properly presented research problems, other elements typical for the work as a research. These are primarily hypotheses. The author in his work is trying to prove that the ongoing conflict left its mark on Ukrainian society, causing a deep division between supporters of the Ukrainian state and those who stood on the side of Russia. It is possible to distinguish clearly indicated testing methods of achieving the intended purpose. The primary method is the so-called participating observation. It is possible to point out that the author's intentions concerning the conduct of it in an objective way tend to be an extremely difficult task in the existing circumstances. It is not easy to keep the due cognitive distance and skilfully evaluate the sources of information. This alone is a major challenge, bearing in mind that we are talking about living people affected by the huge tragedy and torn by huge emotions. In addition, it is difficult not to take into account the fact that the points of view, with respect to the analyzed events, are as many as the number of encountered people on the author's way. Despite this, Paweł Pieniążek is predisposed to enable proper evaluation and analysis of collected data, while being in the centre of events. Particular attention was devoted to the inhabitants of the destroyed cities whose dreams of a normal life have been shattered. In contemporary literature, most works of this type focus on the course of military actions or the analysis of the attitudes and experiences of fighting people. However, the survival experiences of the people living in the center of the conflict are overlooked. Therefore, the reviewed publication, in addition to cognitive character, seems to be the perfect complement of the cognitive base of the conflict in eastern Ukraine which is incorporated on many levels.

"Pozdrowienia z Noworosji" is composed of ten chapters. Each one relates to a separate matter played out mostly in a separate place and time. The first few chapters of the book are an analysis of the political dimension of war. The presented facts relate to the position and actions of Kiev since the Maidan until open military actions in the east of Ukraine as well as the attempts to reach the decision-making centers of pro-Russian activists. It can be argued that the author objectively presents the events, as evidenced by efforts to report back incentive on both sides of the conflict and their point of view, showing the absurdity of the war. Analyzing the situations that gave birth rebellion in the Donetsk, Lugansk, and the surrounding areas, Paweł Pieniążek draws particular attention to: the disbelief of the Ukrainian state supporters on actions that Russia has performed, bringing the official power in the hands of extremists, and the lack of appropriate response of authorities on the state system breakdown. Passivity and 
corruption were therefore the beginning, but also a kind of breeding ground for further destruction of the Ukrainian state and the opportunity for further deterioration of the situation.

In the second part of his work, Paweł Pieniążek analyses the relationship of open war, devoting much attention to the inhabitants of areas affected by the conflict. The purpose of this section is primarily to show the consequences of war, interacting both in a physical and a mental way with its participants. The author notes that people living in areas of Donetsk and Lugansk are mainly characterized by fatigue of war or even indifference. Mostly they do not pay attention to political issues. Their goal is a peaceful life, striving to meet the basic needs of getting a job and food. As the examples he gives conversations which are kinds of psychological portraits of people. One of them shows a man sitting on the bench who, despite the ongoing bombing, remains calm, and he explains his passivity saying that there's nothing to be afraid of because he was baptized. The indifference to the unfolding events sometimes manifests itself even with a lack of interest in which side is currently closer to victory. Of course there are lots of people fanatically looking at the actions of one of the sides of the conflict among the encountered residents.

The author tries to make the information provided have the greatest educational value and to be original. He is one of the first journalists to reach the wreckage of a shot down plane of Malaysian airlines by the separatists, which enables him to illustrate how the bodies had been "used" for political manipulation. The description of this event contains emotions that accompanied the involved people. It rarely happens that the author judges the surrounding reality, but once that happens, the expressed opinion does not offend the reader. It is worth quoting one sentence which reveals his opinion: "None of the previous conflicts in Ukraine has not shaken the society as much as the current conflict." The author, while analyzing the situation, raises questions about its possible consequences in the long term. First of all, the question is who will rebuild the destroyed areas and what will come into existence within the borders, when the conflict is resolved.

From the beginning of the book the author claims that "Pozdrowienia z Noworosji" is not a complete study of ongoing events and that it was issued in haste. Despite this cautious announcements, one has to admit that there can actually be seen a few technical errors visible to the reader, such as typos or editorial shortcomings. It should also be noted that reading about the cities which do not function and the people deprived of normal lives the reader raises some questions of completely prosaic nature. What about the patients evacuated from hospitals or civilians deprived of medication? You do not always need a full answer, it would be enough if the author just pointed out that there is a problem. When it comes to aesthetics, the book as a whole is pleasing to the recipient's eye, however, a large number of photos and stylish black sides separating individual chapters make the impression that there is less content than you might think, without these additions the book would certainly be thinner, cheaper, and thus more accessible. 
To sum up, one can conclude that the author's intention was to present the facts in a concrete manner without undue finesse, which for such dramatic events is entirely appropriate. The book sheds some light on facts that should be remembered. It reflects the spirit of the people who are forced to live in areas plunged into war. The cognitive objective, assumed by the author, has been achieved. "Pozdrowienia z Noworosji" is certainly a valuable book. It seems that it was written for a specific audience. The author requires from the reader certain, basic knowledge of the state, which is the subject of analysis. Assuming that, the author does not deal with the description of basic issues. This makes certain demands on the reader, but on the other hand, he quickly deals with the analysis of the essence of the problem and its detailed aspects, providing very interesting observations.

The work has undoubtedly scientific value. This is a kind of empirical study carried out in difficult conditions. It is worth noting that the publication also provides the material for subsequent researchers who are unable to rely on such type of own material. It is possible to add that it is a position that should interest anyone who is interested how a war reporter works. Even if it was not the intention of the author, the publication can be a peculiar methodological case study, a type of case study methodology coursebook, regarding the conduct of operations (as a reporter). Therefore for these reasons, the analyzed publication can be recommended to people who study the problems of the conflict in Ukraine from the social, political or internal security viewpoint. 